\title{
Estado, audiovisual e políticas de memória. As ditaduras latino-americanas nos documentários do canal argentino Encuentro (2016)
}

\author{
Tatyana de Amaral Maia ${ }^{1}$
}

Gérson Wasen Fraga ${ }^{2}$

Resumo: O objetivo deste artigo é investigar a produção audiovisual dedicada às ditaduras latino-americanas por meio dos curtas-metragens veiculados pelo canal de TV pública argentina Encuentro. Em 2016, o canal lançou na TV, no site e na plataforma youtube, oito curtas-metragens, de caráter documental, sobre as ditaduras latinoamericanas no século XX. Os curtas-metragens de caráter educativo podem ser compreendidos como parte da construção de Histórias públicas marcadas pela adoção de uma política de memória na Argentina dentro do quadro de Justiça de Transição empreendido pelo país, após o final da sua última ditadura (1976-1983).

Palavras-chave: políticas de memória, documentários, ditaduras latino-americanas

\section{State, audiovisual and politics of memory. Latin-American dictatorships on the documentaries of the argentine Encuentro Channel (2016)}

\begin{abstract}
The aim of this paper is to investigate the audiovisual production dedicated to the Latin-American dictatorships through the documentaries broadcasted by the Argentinian public TV channel, Encuentro. In 2016, the channel released on TV, on the website and on the YouTube platform, eight short films, of documentary genre, on the Latin-American dictatorships in the 20th century. The short educational films can be understood as part of the construction of public Histories marked by the adoption of politics of memory in Argentina within the framework of Transitional Justice undertaken by the country, after the end of its last dictatorship (1976-1983).
\end{abstract}

Keywords: politics of memory, documentaries, Latin-American dictatorships.

Artigo recebido em: 30/01/2020

Artigo aprovado para publicação em: 01/03/2020

1 Pós-Doutorado em História na UFF e na Universidade do Porto. Doutora em História (UERJ). Professora adjunta da Escola de Humanidades e do PPGH da Pontifícia Universidade Católica do Rio Grande do Sul (PUCRS). Projeto Atual: Imagens públicas: culturas políticas, cinejornais e ditadura militar (1967-1979). Edital Universal CNPQ 2017/2020; Avenida Ipiranga, 6681, Partenon, Porto Alegre, RS, bloco 08/09, sala 412,05. Cep: 90619-900. tatyana.maia@ pucrs.br.

2 Pós-Doutorando em História no PPGHC-UFRJ. Doutor em História (UFRGS). Professor associado do curso de História, do PPGH e PPGICH da Universidade Federal da Fronteira Sul (UFFS). RS-135, 200 - Zona Rural, Erechim - RS, 99700-000.gwfraga@terra.com,br. 
As políticas de memória dedicadas à promoção da democracia e ao estabelecimento da verdade acerca das ditaduras latino-americanas fazem parte do conjunto de medidas adotadas por diversos Estados que vivenciaram após a $2^{\mathrm{a}}$ Guerra Mundial graves violações de Direitos Humanos. Dentre o conjunto de iniciativas, prevêse que os Estados produzam ações que incluam um tratamento educativo e crítico sobre seus passados sensíveis.

As disputas narrativas em torno das memórias sobre o passado ditatorial recente revelam os diversos usos políticos do passado. Trata-se de uma arena altamente conflituosa. As tentativas de reconciliação nacional não significaram a construção de uma narrativa consensual sobre o passado vivido. Ao contrário, as sociedades que viveram experiências traumáticas se veem desafiadas a construir uma memória capaz de trazer luz sobre tais vivências e também em reforçar a importância dos Direitos Humanos como uma conquista da modernidade. A justa reivindicação por memória e justiça tem mobilizado diferentes grupos nas sociedades latino-americanas (grupos de direitos humanos, familiares de vítimas e vítimas sobreviventes do sistema repressivo, intelectuais, políticos progressistas, parte da imprensa, segmentos da Igreja Católica, alguns setores mais críticos das Forças Armadas, entre outros). Ao mesmo tempo, a tentativa de construção de uma memória centrada nos Direitos Humanos não impede o aparecimento de discursos negacionistas ou ainda marcados pela já caducante, mas ainda viva, "Teoria dos Dois Demônios", sobretudo, no caso do Cone Sul. No entanto, é preciso registrar que a maneira como os Estados tratam politicamente os seus passados dolorosos nos revela muito mais sobre o processo de redemocratização vivido - se por ruptura ou negociação, por exemplo - do que sobre a experiência ditatorial em si (BRITTO, GONZÁLEZ-ENRÍQUEZ, FERNANDES, 2004, p. 155). Nessa perspectiva, é preciso considerar as especificidades dos processos de redemocratização de cada país na adoção dos instrumentos de Justiça de Transição. Em artigo sobre o tema, Glenda Mezarobba destaca quais as ações esperadas pelos defensores de Direitos Humanos para o tratamento das graves violações cometidas pelos Estados no pós-Guerra: 
Isso geralmente envolve uma combinação de estratégias judiciais e nãojudiciais complementares, tais como processar criminosos; estabelecer comissões da verdade e outras formas de investigação a respeito do passado; esforço de reconciliação em sociedades fraturadas; desenvolvimento de programas de reparação para aqueles mais afetados pela violência ou abusos; iniciativas de memória e lembrança em torno das vítimas e a reforma de um amplo espectro de instituições abusivas em tentativas de evitar novas violações no futuro. (MEZAROBBA, 1996, p.113).

No caso argentino, o processo de Justiça de Transição e, por conseguinte, as políticas de memória foram altamente variáveis nas últimas décadas, com períodos de maior ou menor alcance. Ainda que considerado um modelo no quadro de ações em busca da verdade, da justiça e da reparação possível, as políticas de memória e de justiça na Argentina, após o seu processo de redemocratização, foram fruto de uma intensa disputa política e de narrativas sobre como lidar com seu doloroso passado recente. Os autores dedicados à compreensão do processo de Justiça de Transição argentino têm considerado o ano de 2003 como um marco. A partir de então, o país passou a adotar políticas públicas sistemáticas e cada vez mais amplas dedicadas a tratar do seu passado ditatorial recente (LVOVICH e BISQUERT, 2008, p.7). A partir da chegada de Néstor Kirchner (2003) à presidência da República, inicia-se uma política de memória do Estado que consagrará determinadas narrativas e consolidará a imagem da Argentina como o país que adotou com maior amplitude, no Cone Sul, os instrumentos da Justiça de Transição. Será no governo Kirchner, como demonstram Lvovich e Bisquert (2008, p.79), que foram anuladas as leis de impunidade, como ficaram conhecidas as Leyes de Obediencia Debida e Punto Final. Foram também adotadas medidas de promoção da justiça que levaram à punição de vários agentes de Estado responsáveis por torturas, mortes e desaparecimentos forçados, além da promoção de uma série de ações em busca da verdade e do direito à memória. A partir de então, a questão de Direitos Humanos se tornou fundamental para Kirchner, sendo cada vez mais presente no seu projeto político:

El gobierno de Kirchner, que buscaba por diversas vías generar mecanismos que le permitieran superar la debilidade de origem que representaba el escasso porcentaje de votos com el que había llegado al poder, encontró a partir de entoces en buena parte del movimento por los derechos humanos un aliado permanente. (LVOVICH e BISQUERT, 2008, p.7). 
Nesse contexto, o Ministério da Educação e Cultura argentino criou o Canal Encuentro, o primeiro canal da Argentina dedicado à promoção da educação e à circulação de conteúdo crítico sobre os mais variados temas. Em 2016, em parceria com a produtora LumaDOC, o canal lançou uma série com oito curtas-metragens sobre as ditaduras latino-americanas, um para cada país selecionado.

O objetivo deste artigo é analisar as representações acerca das ditaduras latinoamericanas produzidas pelos oito curtas-metragens do Canal Encuentro como parte integrante das políticas de memória argentina. A hipótese deste artigo é que tais curtasmetragens, de caráter documental, concorrem na construção de uma narrativa pública da História, a partir da centralidade do debate acerca dos Direitos Humanos, tornando-se, portanto, parte integrante das ações de Justiça de Transição e apresentando os governos Kirchner (2003-2007; 2007-2015) como críticos mordazes do neoliberalismo. Nessa perspectiva, os documentários expõem temas caros às disputas de sentidos sobre o passado ditatorial argentino e também latino-americano, tais como: o Terrorismo de Estado; a interferência da diplomacia norte-americana nas trajetórias políticas latinoamericanas; o anticomunismo; a participação e apoio de vários segmentos da sociedade civil nos golpes e regimes autoritários, bem como os efeitos nefastos das políticas neoliberais (nos casos das ditaduras em que tal modelo econômico foi implementado). Ainda que a centralidade dos curtas-metragens esteja na questão dos Direitos Humanos, considerado o aspecto fundamental da Justiça de Transição, há espaço para críticas ao modelo neoliberal implementado por algumas ditaduras latino-americanas. O casal Néstor Kirchner e Cristina Kirchner, durante seus respectivos governos, foram críticos vorazes do avanço do neoliberalismo na Argentina, tendo como plataforma de governo a construção de alternativas políticas à pressão constante do mercado por reformas neoliberais.

\section{Usos do passado e TV pública na Argentina: a função pedagógica e a produção de conteúdo no projeto do canal Encuentro.}

O interesse crescente pelo passado nas sociedades contemporâneas é parte de um processo de emergência de uma cultura da memória, fenômeno considerado por Andreas 
Huyssen como parte integrante da modernidade. Ao identificar a existência de uma "hipertrofia da memória" como resultado da experiência moderna, em especial após a $2^{\mathrm{a}}$ Guerra Mundial, Huyssen propõe que a formação de uma cultura da memória se desenvolveu em escala transnacional tendo como espinha dorsal o fenômeno traumático do Holocausto. A partir de então, a questão dos Direitos Humanos, do dever de memória e do direito à verdade atravessou transnacionalmente todos os países marcados por eventos traumáticos, sobretudo no final do século XX (caso das ditaduras latinoamericanas e da África do Sul), ainda que as especificidades nacionais definissem as formas de lidar com esse passado. Nesse contexto, o uso massificado de novas tecnologias, o fenômeno das sociabilidades virtuais e a circulação instantânea de informação em escala global não romperam com a importância do passado na construção de projetos de futuro. Ao contrário, observa-se um boom da memória com amplo mercado consumidor (HUYSSEN, 2014, p. 139).

A globalização da memória não se restringiu aos lugares de memória tradicionais como museus, monumentos, arquivos ou ainda publicações impressas. Ela fez uso ostensivo das novas mídias que passaram a concorrer com espaços institucionalizados de memória. Outro fator importante é que longe de estar enquadrada por uma memória nacional que se pretende coesa e amplamente compartilhada, ela emergiu em uma arena política conflagrada, minimizando a possibilidade de construção do consenso e fortemente marcada pela contínua reelaboração de uma memória pública do trauma histórico. A construção pública dessas memórias conflagradas ocorrerá a partir da atuação de diversos atores sociais que concorrem entre si pela autoridade do discurso. As instituições tradicionais e seus agentes (imprensa, escolas, universidades, centros de pesquisa, museus, arquivos) controlaram durante a maior parte da modernidade as representações do mundo social, dada a autoridade e legitimidade conferida ao conhecimento cientificamente orientado. O audiovisual, as redes sociais e as novas mídias criaram outras formas de legitimidade e autoridade sobre as narrativas históricas, muitas vezes embaralhando os campos da memória e da história. A legitimidade e a autoridade de uma narrativa também passaram a ser construídas pela visibilidade e aceitabilidade de um produto virtual que rapidamente viralize nas redes sociais e passe a ser compartilhado 
pelos milhões de acessantes da rede mundial de computadores (BURGUESS e GREEN, 2009, p. 22).

A produção de narrativas sobre esse passado para o grande público, realizada não apenas por historiadores, mas por profissionais de diversas áreas da comunicação e também por "entusiasmados praticantes comuns" (LINDDINGTON, 2011, p. 46), tem se tornado objeto de reflexão e pesquisa. Tais narrativas, quando dedicadas ao passado recente e associadas à produção audiovisual, tendem a articular a História, a memória, cultura visual, a ética e a política, que passam a concorrer na conformação de um produto que se baseia na tríade "informação, conhecimento e entretenimento," influenciando na formação da nossa consciência histórica.

Nesse heterogêneo universo de produção de comunicação de massas, é possível encontrarmos na produção audiovisual de conteúdo histórico a circulação de diversas narrativas que usam (e abusam) politicamente do passado na construção de sentidos do mundo social. A produção e circulação de narrativas sobre o passado se multiplicou nas últimas décadas nos diversos países do globo, impulsionadas pela facilidade de acessar o público a partir da expansão da rede mundial de computadores, do desenvolvimento tecnológico e da multiplicação de possibilidades disponíveis nas mídias sociais.

As mídias passaram a interagir com tradicionais lugares de memória e com os centros de produção do conhecimento, modificando a relação hierarquizada entre aqueles que detêm cientificamente a legitimidade do discurso e os demais sujeitos históricos. Nas redes sociais, as complexas interações entre memória e história se tornaram ainda mais visíveis e problemáticas.

O sucesso dos audiovisuais de conteúdo histórico são a expressão de uma “explosão de representações populares do passado" (LIDDINGTON, 2011, p.32). Essa cultura da memória, fundamentalmente ancorada nas mídias e no consumo cultural de massas tem seus efeitos sentidos na cultura pública da memória e na história visual contemporânea (HUYSSEN, 2004, p.134).

No caso específico do objeto deste artigo, o canal Encuentro é, antes de mais nada, o resultado de políticas de Estado do governo argentino, tendo como proposta a democratização da informação, entendida como necessária na construção de narrativas plurais e dissonantes. Além do caráter educativo, o canal pretende produzir conteúdo de 
qualidade também no campo da informação, do entretenimento e da cultura, apresentando-se como uma alternativa à hegemonia narrativa exercida pelos tradicionais meios de comunicação naquele país, entendidos pelos governos do casal Kirchner como regidos pelo paradigma neoliberal de comunicação de massas.

Embora tenha realizado suas primeiras transmissões em 05/03/2007, a história de Encuentro remonta a 2004, quando Daniel Filmus - sociólogo e então ministro da Educação, Ciência e Tecnologia no governo de Néstor Kirchner - passou a idealizar a existência de um canal de televisão exclusivamente educativo. Para tanto, dois caminhos foram paralelamente trilhados. Por um lado, foi criado no âmbito do ministério o Programa de Meios Audiovisuais, tendo como objetivo iniciar os trabalhos para levar ao ar um sinal de TV público e educativo. Ao mesmo tempo, na Universidade Nacional de San Martín, desenvolvia-se um projeto de pesquisa sobre os diversos modelos de canais educativos existentes no mundo, ao mesmo tempo em que se propunha uma avaliação dos programas educativos criados ao longo da história televisiva argentina, analisando os motivos de sucesso e fracasso. Tal pesquisa era conduzida pelo professor e cineasta Tristán Bauer.

A convergência entre esses dois caminhos levou Filmus e sua equipe à decisão de vincular o canal a ser criado à estrutura da empresa estatal "Educ.ar". Por um lado, essa escolha facilitaria as ações no campo jurídico e administrativo, agilizando o processo (a vinculação do canal a uma universidade ou simplesmente ao Ministério da Educação demandaria um período de contratações e licitações que por si só inviabilizariam o projeto). Por outro, pensava-se já nesse momento que o desenvolvimento de um novo sinal de televisão, com caráter público e educativo, não poderia abrir mão da convergência com a internet. Dessa forma, a estrutura que ainda se idealizava já era projetada para operar dentro de múltiplas plataformas, potencializando a difusão de seu projeto educacional com ampla capacidade de difusão entre o maior público possível (CORTE, 2016, p. 362).

Os dois anos seguintes foram dedicados ao trabalho de montagem do aparato jurídico e administrativo do novo canal, ao mesmo tempo em que os eixos de produção e programação passaram a ser idealizados. Segundo Malena Corte (2016, p.363), a proposta inicial contemplava a aquisição de materiais produzidos por instituições públicas e 
privadas da Argentina e de outros países, bem como de produções realizadas no âmbito universitário. Estipulava-se também um espaço para a produção interna, ainda que delegada a terceiros (IDEM).

Em 2008, Tristán Bauer foi nomeado pela então presidente Cristina Kirchner como Diretor do Sistema Nacional de Meios Públicos. É nesse momento que se incorpora uma percepção importante ao projeto televisivo de Encuentro e das demais televisões públicas argentinas: a programação, para além de seu caráter educativo, deveria também ser interessante para o grande público, afinal, trata-se de televisão (CORTE, 2016, p.365).

Contudo, se o projeto de Encuentro pressupunha um canal de TV que aglutinasse em sua programação educação e qualidade, havia, no início das transmissões, um desafio a ser superado: o fato de que seu sinal só era acessível a quem dispusesse de TV a cabo (e que portanto pudesse pagar uma determinada mensalidade para acessar a programação). Tal questão seria resolvida por meio de duas formas: a primeira, por meio da instalação da Tevê Digital Aberta (TDA) na Argentina a partir de 2010 (o que ainda requeria a compra e instalação de um conversor), e a segunda, certamente mais efetiva, pela disponibilização da programação por meio da rede mundial de computadores. Aqui entramos no que é, de fato, o traço distintivo de Encuentro: a abrangência pública de seu caráter educativo. Segundo Diaz:

\footnotetext{
La aparición de Encuentro constituye 'un momento bisagra en lo relativo a TV pública en este país porque no relegó calidad en contenidos, técnica ni narrativa. Sin embrago no és solo un señal, sino un proyecto educativo multiplataforma que replica los contenidos en su web permitiendo descargar las temporadas ya emitidas y propone un espacio docente con recursos complementarios a los vídeos para el trabajo en clase (DIAZ, 2013, p. 40).
}

Essa preocupação em vincular a produção televisiva com possibilidades de trabalho em sala de aula é, com efeito, o grande diferencial de Encuentro. Contudo, sua missão é percebida por seus analistas como algo que vai muito além da produção de materiais audiovisuais com possibilidades didáticas. Trata-se também de pensar a qualidade da educação; o papel do poder público na definição de políticas de comunicação e na democratização dos meios, assegurando a pluralidade de opiniões e, principalmente, se contrapondo à midiocracia (entendida como a colonização da política pelos meios de comunicação). Segundo Dias, 
para situar en la agenda los temas de los ámbitos acadêmicos y de las organizaciones sociales, fue determinante la iniciativa del Estado para desarrollar reformas parciales en matéria comunicacional. En ese sentido, canal Encuentro significó el início de la ruptura del paradigma neoliberal de la comunicación (DIAZ: 2013, p. 40).

Insere-se assim o direito à comunicação na arena dos direitos politicamente disputados. Torna-se evidente, portanto, que o projeto que levou à criação do Canal Encuentro tocava em algo muito mais profundo que a mera criação de mais um sinal televisivo de natureza pública. Tratava-se, antes, da percepção de que um projeto nacional, qualquer que ele fosse, passaria necessariamente por projetos de comunicação que levassem em conta a importância das diversas disputas narrativas acerca da História, em especial da História recente, junto à população, disputando assim corações e mentes junto às narrativas hegemônicas pautadas pela discursividade do mercado neoliberal. Sobre isso, falam-nos Duran et alii ao afirmarem:

\footnotetext{
Un proyecto de país pone en circulación un relato de su história. A tono con su construcción política y en correlato con acciones concretas para la reparación de los crímenes de Estado llevados a cabo durante la última dictadura cívico militar, durante el período conocido como gobierno kirchnerista se construyó desde distintos espacios y de manera colectiva, un relato sobre la história reciente (DURAN et alii. s/d, p 2).
}

A partir dessa perspectiva, diversos projetos foram desenvolvidos no canal. Merecem destaque as produções dedicadas aos temas da chamada nova esquerda e que emergiram com força no continente latino-americano a partir do final dos anos de 1970 e, sobretudo, ao longo dos processos de redemocratização. Assim, Encuentro reúne em sua programação temas dedicados aos feminismos, às imigrações, ao meio ambiente, aos direitos humanos, à legalização das drogas, ao aborto voluntário, com uma agenda bastante progressista. O canal oferece conteúdo seguindo os padrões tecnológicos circulantes entre os meios de comunicação de massa, com técnicas apuradas para a produção de som e imagem de qualidade. O canal também mantém um diálogo profícuo com os meios acadêmicos, convidando intelectuais e cientistas para abordarem os temas contemporâneos mais diversos. 
Dentre esses projetos, destacamos os oito curtas-metragens produzidos em 2016 sobre as ditaduras na Argentina (1976-1983), no Uruguai (1973-1985), no Chile (19731990), no Paraguai (1954-1989), no Brasil (1964-1985), na Bolívia (1964-1982), na Venezuela (1948-1958) e no Equador (1972-1979), compondo a série Dictaduras LatinoAmericanas. A metodologia de análise desses curtas-metragens seguirá a análise em conjunto da imagem e do som, concentrando-se na recorrência dos sentidos produzidos para essas ditaduras e que põem em perspectiva comparativa as experiências ditatoriais compartilhadas por esses oito países no período da Guerra Fria. Além disso, em termos teóricos, seguimos a classificação analítica proposta por Fernão Ramos para definir esses curtas-metragens como documentários:

Em poucas palavras, documentário é uma narrativa com imagens-câmera que estabelece asserções sobre o mundo, na medida em que haja um espectador que receba essa narrativa com asserção sobre o mundo. (...) Ao contrário da ficção, o documentário estabelece asserções ou proposições sobre o mundo histórico. (RAMOS, 2008, p. 22).

Entendemos, portanto, que esses curtas-metragens são documentários de curta duração ao produzirem assertivas que são compreendidas pelo espectador como proposições acerca do real. Tal característica dos documentários os torna um instrumento singular na construção de representações do mundo social.

\section{A série Dictaduras Latino-Americanas e os sentidos do passado no audiovisual}

A série Dictaduras Latino-Americanas é formada por um conjunto de curtasmetragens sobre a emergência de regimes ditatoriais na América Latina no pós-2 $2^{\mathrm{a}}$ Guerra, com destaque para a interferência norte-americana, a adoção do Terrorismo de Estado e a violação dos Direitos Humanos. Produzidos a partir da clássica técnica de voz over, na qual o narrador é quem conduz todo o enredo fílmico, os curtas-metragens possuem duração de 12 a 14 minutos, mantendo o mesmo padrão audiovisual, qualificando-os como uma mesma e continua série. A ordem de apresentação da série não segue nenhum padrão facilmente identificável, mas chama atenção o fato do primeiro país da série ser a Argentina. O narrador comporta-se como um detetive investigando os arquivos dos 
regimes ditatoriais em busca da verdade. Em uma atuação parecida com a de um historiador, ele busca relatórios, documentos oficiais, fotografias e qualquer vestígio embolorado pelo tempo que pudesse recontar estes anos sombrios do continente.

O conjunto de documentários acerca das ditaduras latino-americanas é produzido pelo canal Encuentro com a proposta de utilização também em sala de aula ainda que essa série, diferentemente de outras do mesmo canal, não apresentasse atividades didáticas complementares. Ao mesmo tempo, os curtas-metragens também possuem um caráter informativo e apresentam narrativas coerentes acerca do passado ditatorial recente vivido pelos países latino-americanos. Dos doze países sul-americanos, oito (Argentina, Bolívia, Brasil, Chile, Equador, Paraguai, Uruguai e Venezuela) são objeto de reflexão a partir das chaves narrativas construídas pela adoção de políticas de memória nos governos Kirchner alinhados aos grupos de Direitos Humanos e aos familiares das vítimas da ditadura argentina. Concorrem, portanto, nessa arena conflituosa para a construção de uma memória hegemônica que por vezes associa os direitos humanos à crítica ao modelo neoliberal de gerenciamento dos Estados-nação.

Ainda que o elo entre essas oito narrativas esteja na ocorrência dos regimes ditatoriais que assolaram a América do Sul durante a segunda metade do século XX, a série busca apresentar as especificidades do fenômeno em cada país, o que acaba por gerar alguns episódios com caráter mais específico, como o dedicado à Venezuela, que apresenta uma temporalidade diversa em relação aos demais.

Todavia, alguns elementos são citados sistematicamente ao longo da maioria dos oito episódios, conferindo-lhes a necessária ideia de unidade e servindo como exemplo do caráter didático almejado pela série. Tomemos como ilustração, nesse sentido, a denúncia da Operação Condor, citada ao longo das narrativas sobre Argentina, Brasil, Chile, Paraguai e Bolívia (ainda que nesta com menor ênfase) e dos vínculos desse aparato repressivo internacional com os interesses estadunidenses acerca da América do Sul. A explicação sobre o que foi a Operação Condor é acompanhada da imagem em animação de um Condor sobrevoando a Cordilheira dos Andes. Após um breve pouso, a ave retoma seu voo, transformando-se em uma águia norte-americana, no mesmo momento em que a cordilheira ao fundo assume o design de uma bandeira estadunidense. 


\section{IMAGEM 1}

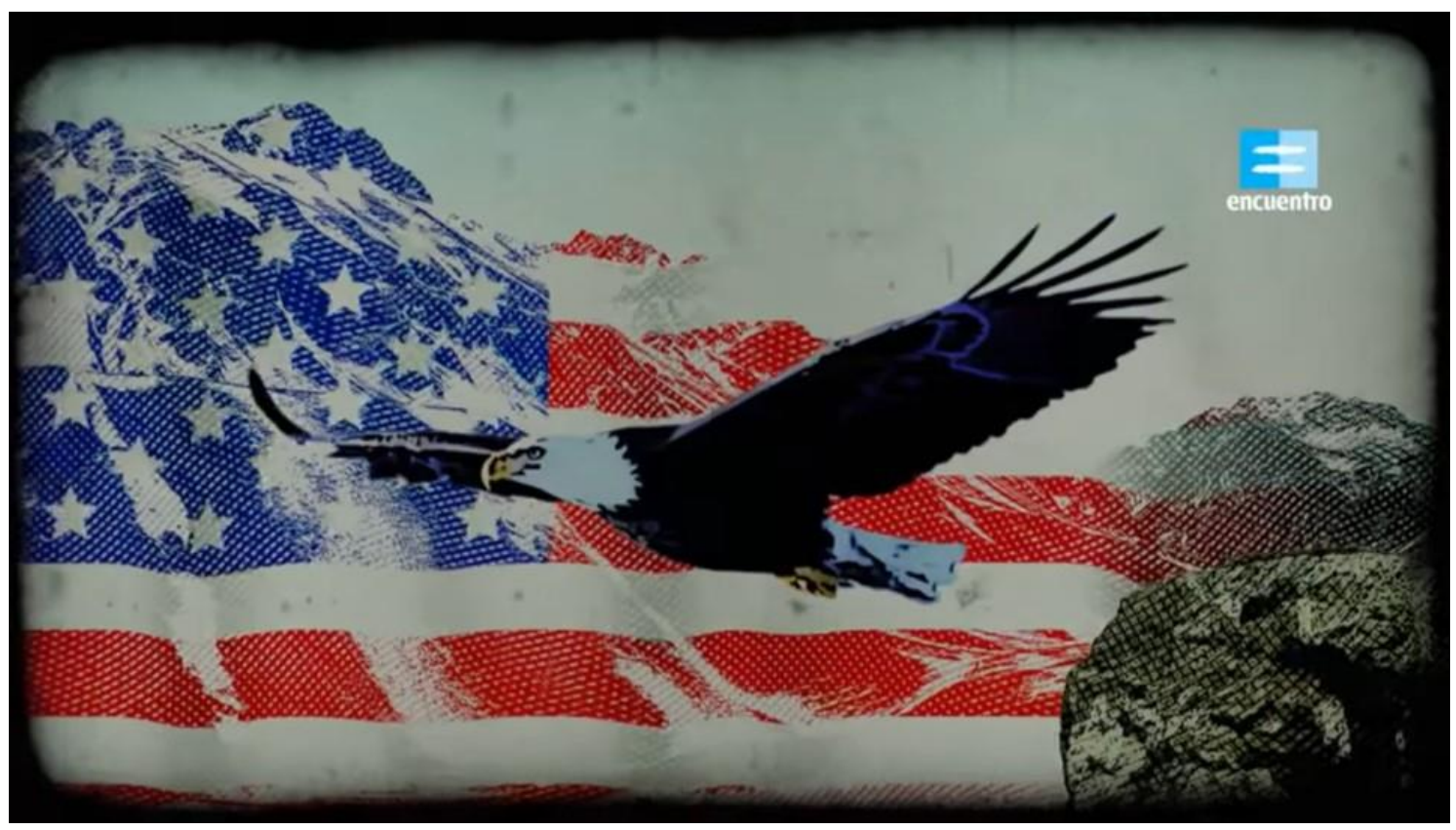

Fonte: Canal Encuentro, Dictaduras Latino-Americanas, Uruguay, 2016, 2:44.

https://www.youtube.com/watch?v=TbV9SUh9chA\&list=PLD9uJ4b9DO5DYlETfre1uoOT1j2tNZ19m\&i $\underline{\text { ndex }=2}$ acesso: $20 / 12 / 2019$

Ao mesmo tempo, a narrativa evidencia que, apesar de ser conduzida pelas mãos dos militares sul-americanos, a operação defendia paralelamente os interesses políticos e econômicos dos Estados Unidos ao implantar no continente as Ditaduras de Segurança Nacional e o Terrorismo de Estado surgidos dentro do contexto da Guerra Fria em diversos países no continente latino-americano, através da criação da imagem de um inimigo interno e subversivo ancorado em uma suposta "ameaça comunista" (PADRÓS, 2007, p.48). Embora possa causar a princípio alguma estranheza, o fato de a mesma animação e explicação aparecer em cinco episódios da série nos ajuda a compreender como a narrativa evidencia que cada um daqueles espaços esteve envolvido em um contexto repressivo semelhante, muito embora as especificidades locais possam ser destacadas ao nos referirmos a cada país. A ênfase, portanto, recai sobre a interferência 
norte-americana no continente, apresentando-a como o motivo central para a adoção das ditaduras.

Deve-se destacar que as narrativas estão calcadas em um amplo conjunto de elementos. Inicialmente, somos conduzidos ao longo da série por duas personagens com funções específicas, porém complementares. Inicialmente, o uso da técnica de voz over (o "narrador oculto") nos acompanhará ao longo de todos os episódios, chamando nossa atenção para os diversos elementos que compõem a linha argumentativa da série. Em segundo lugar, a figura de um pesquisador trabalhando em um arquivo, munido de lupa e cercado de documentos confidenciais possui o objetivo de criar a sensação de que novas informações estão sendo descobertas sob o pó do tempo e do esquecimento. A figura do pesquisador pretende assim realizar o papel de um alter ego do espectador, trazendo-o para a narrativa não como uma personagem que tivesse vivido os acontecimentos narrados, mas como o historiador que investiga os documentos e sobre ele produz sua narrativa.

O recurso à animação, por sua vez, pode ser entendido como uma estratégia narrativa de dupla função. Por um lado, há uma evidente ausência de imagens que remetam diretamente ao que está sendo narrado, sendo a animação um recurso para preencher tais lacunas em vez do uso de imagens que poderiam ocupar tal espaço, ainda que remetendo a momentos apenas correlatos à narrativa. Por outro, há uma clara preocupação com a intensidade traumática do fato em questão, como cenas envolvendo torturas ou assassinatos, uma vez que o material produzido se destina, também, ao uso didático em sala de aula. $\mathrm{O}$ recurso à animação nesse momento não retira a intensidade da narrativa, mas atenua seu grau de violência, criando, ao mesmo tempo, um cenário de pesadelo deveras apropriado àquele contexto político. A representação de um militante uruguaio torturado e morto em um centro clandestino pode atenuar a violência evidente, sem retirar o peso da barbárie empreendida pela violência dos agentes do Estado: 


\section{IMAGEM 2}

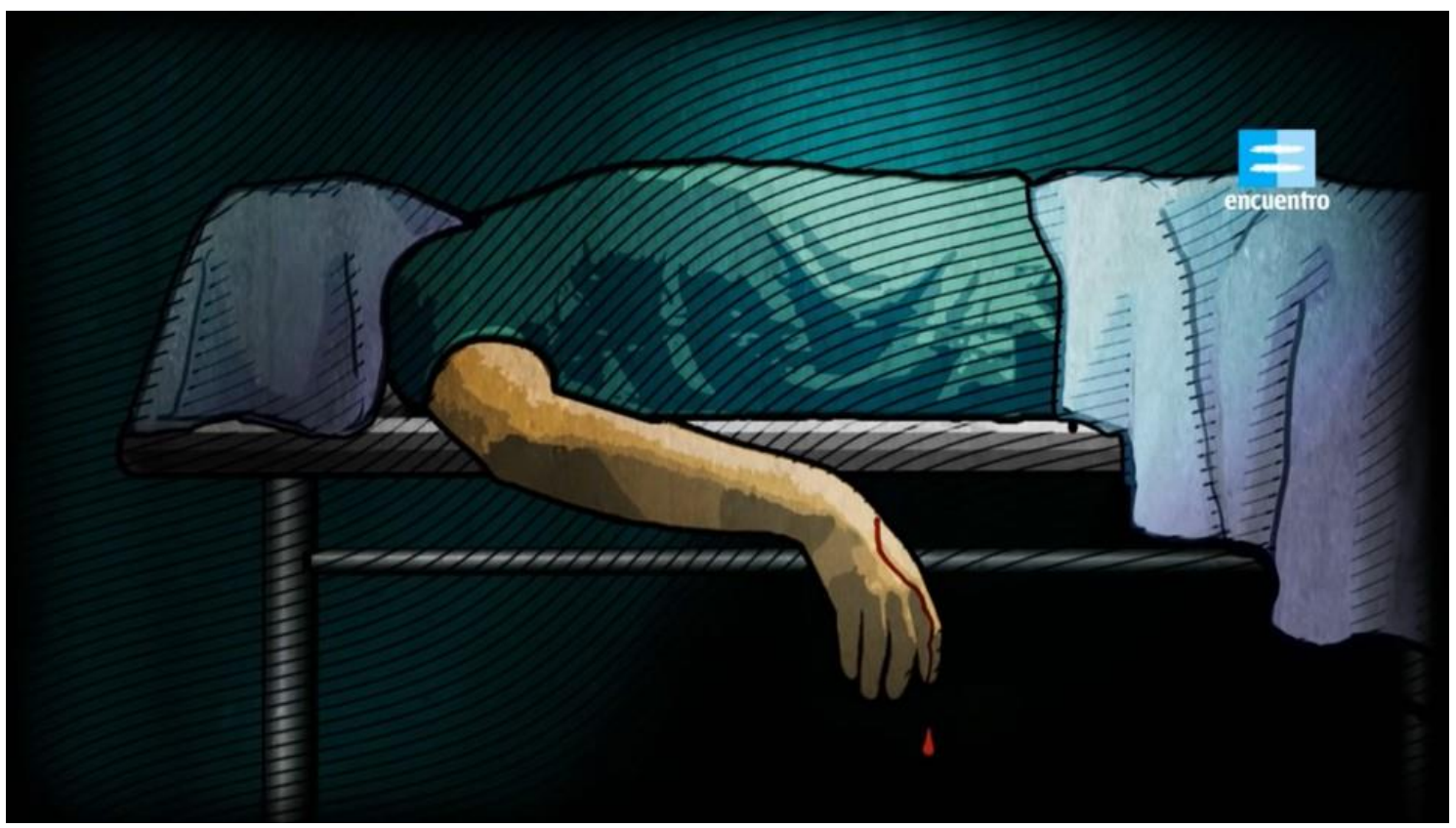

Fonte: Canal Encuentro, Dictaduras Latino-Americanas, Uruguay, 2016, 0:26.

https://www.youtube.com/watch?v=TbV9SUh9chA\&list=PLD9uJ4b9DO5DYlETfre1uoOT1j2tNZ19m\&i $\underline{\text { ndex }=2}$ acesso: $20 / 12 / 2019$

Todavia, os episódios também evidenciam a preocupação em aproximar o espectador de uma ampla gama de "fontes históricas". A todo momento, imagens de época são intercaladas com fotos, imagens de matérias jornalísticas e gravações de discursos oficiais (sobre este último recurso, é curioso notar como a imagem de um gravador de rolo hipoteticamente reproduzindo o discurso que está sendo executado repete-se ao longo dos episódios, assumindo a função já comentada de criar uma aproximação entre o espectador e a figura de um pesquisador em um arquivo). Assim, a narrativa se vale de diversos elementos, conferindo a si mesma o aspecto de uma pesquisa meticulosa que resulta no conjunto apresentado. Ao final de cada episódio, o personagem pesquisador guarda uma pasta referente ao país-tema em um arquivo de aço, concluindo "seu trabalho" (a narrativa), mas também evidenciando que o resultado produzido por sua ação passa a estar disponível para ser acessado em momentos futuros, o que nos denota 
uma certa concepção acerca da natureza e das finalidades do conhecimento histórico. Assim, parece-nos pecar por simplicidade a interpretação de Durán et alii ao analisarem a série Dictaduras Latinoamericanas:

\begin{abstract}
Poniendo como base de la investigación la similitud en los mecanismos de repressión que tuvieron las dictaduras de América del Sur mediante el famoso Plan Cóndor, este programa se propone abordar las causas, consecuencias y modus operandi de las dictaduras militares en Chile, Brasil, Argentina, Uruguay, Paraguay y Bolívia (DURAN et alii, 2014, p. 2).
\end{abstract}

Há, contudo, um sentido mais profundo na construção dessas narrativas acerca das ditaduras sul-americanas por parte de Encuentro e que se associa à própria percepção da necessidade de um canal televisivo público voltado à produção audiovisual educativa. Trata-se da construção de narrativas que se oponham ao discurso neoliberal que se pretendia hegemônico no começo do século XXI. Nesse sentido, cabe destacar que o projeto que leva ao reforço do sistema público televisivo na Argentina ocorre durante os governos kirchneristas, sucessores e herdeiros do Peronismo. Apresentando-se como alternativa ao discurso de hegemonia dos interesses do mercado, os governos de Néstor e Cristina Kirchner buscaram construir os caminhos possíveis para que o pensamento pautado pelo economicismo neoliberal e pelo conservadorismo social não passasse a ditar a História. Ao mesmo tempo, tais usos podem dificultar a construção de uma narrativa histórica a partir dos métodos próprios da pesquisa que buscam controlar as subjetividades inerentes à produção de qualquer conhecimento. Exemplar, nesse sentido, é que um dos fios condutores que perpassam os oito episódios está no desvelamento dos interesses econômicos por trás de cada um dos regimes repressivos analisados, bem como da participação de setores sociais latino-americanos, seja apoiando os golpes, sustentando os regimes ou mesmo participando pessoalmente das sessões de tortura aos presos políticos (como foi o caso do empresário brasileiro Henning Albert Boilesen). Dessa forma, em todos os episódios, são destacados os vínculos dos regimes repressivos e suas práticas de repressão, sequestros, torturas, assassinatos e desaparecimentos com os interesses e lucros financeiros das elites econômicas locais por meio de políticas preconizadas pelo FMI e pelo Banco Mundial, que redundavam em concentração de 
renda, aumento do arrocho salarial, do desemprego e da desigualdade social. Passemos agora a uma análise um pouco mais detalhada de cada um dos episódios.

O episódio dedicado à Argentina inicia com o golpe que derrubou Maria Estela Martínez, em 24 de março de 1976. Contudo, logo se destaca que o golpe não pode ser dissociado de um período politicamente conturbado que já durava duas décadas. Ao mesmo tempo, é ressaltado que, já durante o governo de Maria Martínez, a Argentina encontrava-se cercada por regimes ditatoriais no Cone Sul. Dessa forma, a repressão teria iniciado antes mesmo do golpe, quando da assinatura do "Decreto de Aniquilamento da Subversão", em 05 de fevereiro de 1975, que, por sua vez, levou ao "Operativo Independência”. Já nesse momento pré-golpe, as forças armadas encontraram nos meios de comunicação o veículo para se apresentarem como solução para o caos social e político, encontrando apoio nos setores mais conservadores da sociedade e os segmentos empresariais. O ditador empossado, General Jorge Rafael, Videla, havia sido comandante em chefe do exército sob o governo de Isabel Perón.

Após explicitar o golpe, a imagem e a narrativa destacam a implantação do regime civil-militar, que por meio do terror implementou uma nova ordem socioeconômica: a neoliberal:

\footnotetext{
As Forças Armadas nomearam o seu governo de Processo de Reorganização Nacional. Mas, o objetivo era instaurar através do Terror uma nova ordem econômica e social em linha com o restante das ditaduras latino-americanas associadas no marco do Plano Condor. Assim, utilizaram um plano repressivo internacional que coordenava operações de perseguição, sequestro e tortura a militantes dos distintos países do Cone Sul. (Encuentro, Dictaduras LatinoAmericanas - Argentina, 4:35).
}

$\mathrm{Na}$ imagem referente a esse texto, um quadro no qual as ideias-chave são apresentadas, tal como em uma sala de aula, informa a adoção da política econômica neoliberal. Chama atenção o fato de ser apresentada tal associação generalizada às ditaduras ao neoliberalismo, o que de fato não aconteceu em todos os regimes ditatoriais na América Latina. 


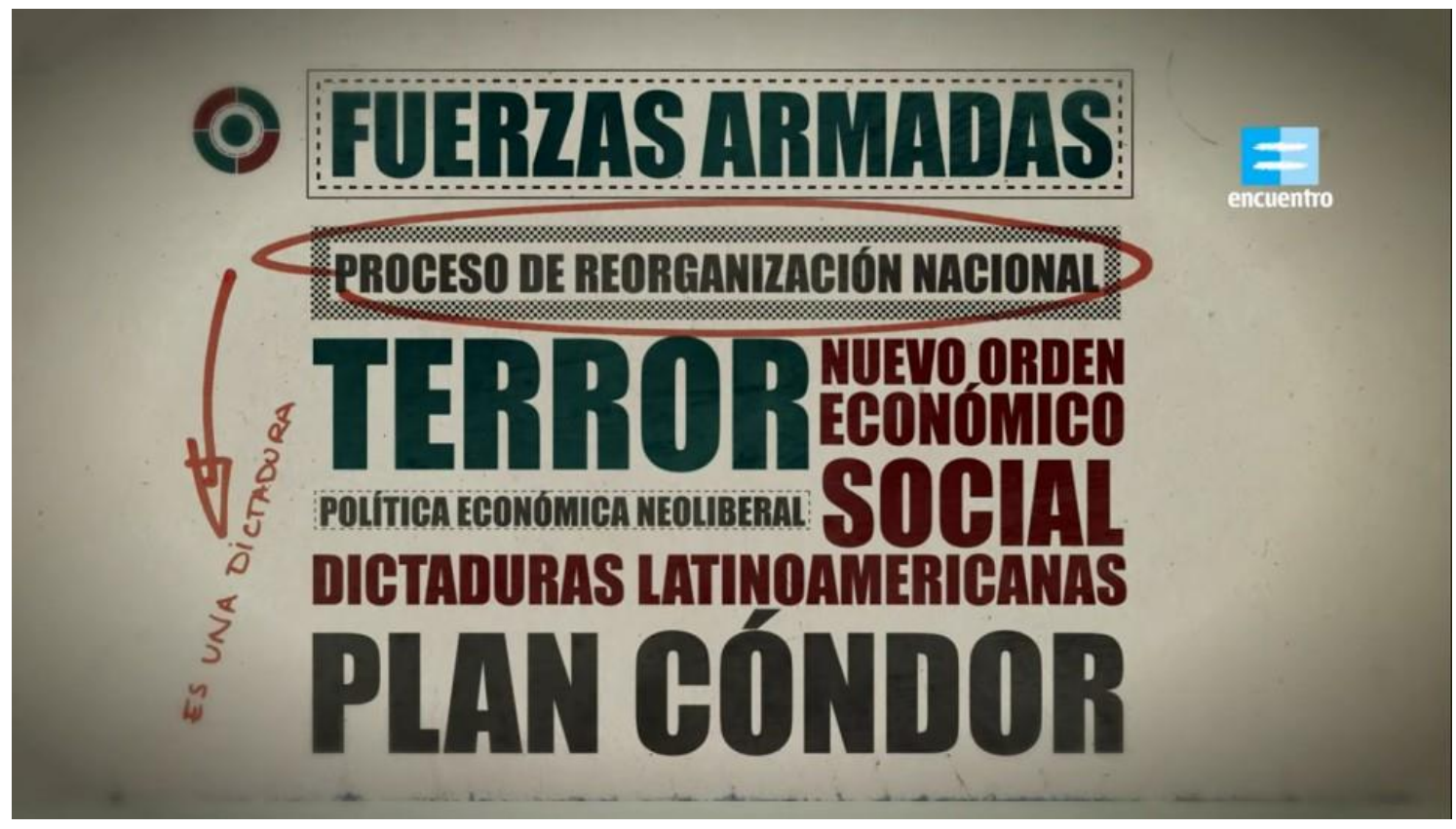

Fonte: Canal Encuentro, Dictaduras Latino-Americanas, Argentina, 2016, 4:35. https://www.youtube.com/watch?v=vfJRbs-4q$\underline{w} \&$ list=PLD9uJ4b9DO5DY1ETfre1uoOT1j2tNZ19m\&index=1 acesso: 20/12/2019

O curta ainda associa a ditadura argentina às demandas do capital estrangeiro, aumentando brutalmente o desemprego e a dívida externa. A intensidade de sua força repressiva associada à força de seu discurso nacionalista nos é ilustrada pela associação do ufanismo que vigorava durante a Copa do Mundo de futebol de 1978 com a existência de mais de 500 centros de terror, tortura e extermínio ao longo do país. Da mesma forma nos é contraposto o cínico slogan do regime militar durante o Mundial (“Los Argentinos son Derechos e Humanos") ao surgimento das Madres de la Plaza de Mayo e sua heroica resistência ao denunciar os desaparecimentos de seus filhos. A aproximação de Nestor Kirchner ao grupo das mães ocorreu imediatamente após a sua posse na presidência da República e permaneceu importante no processo de construção do apoio político ao seu governo (LVOVICH e BISQUERT, 2008, p. 8).

O curta rapidamente passa a tratar da crise do regime, destacando que as brechas no regime autoritário e os problemas sociais passaram a ficar evidentes na medida em que 
a crise econômica de inícios dos anos 1980 ganhou força. Deixando para trás Videla, a narrativa passa a centrar seu foco no governo do ditador Leopoldo Galtieri, em especial na malfadada Guerra das Malvinas (1982), tentativa desesperada do regime militar de reagrupar em torno de si o apoio popular por meio de uma bandeira nacionalista. Como último ato, somos apresentados ao governo de Reynaldo Bignone, que assinou uma lei de autoanistia para os militares, ao mesmo tempo em que ordenava a destruição de documentos que davam conta do conjunto de violações aos Direitos Humanos promovidos pelas forças armadas argentinas ao longo dos últimos anos. Esta lei seria revogada por Raúl Alfonsin, eleito em fins de 1983.

O episódio dedicado ao Uruguai inicia com o sequestro e assassinato do sindicalista Gerardo Gatti, em Buenos Aires, no ano de 1976, evidenciando as conexões da Operação Cóndor e o caráter internacional do Terror de Estado no Cone Sul. Contudo, logo nos é oferecida uma contextualização histórica da política uruguaia ao longo da segunda metade do século XX, polarizada entre Blancos (associados ao campo) e Colorados (representantes dos setores urbanos). Nesse contexto, somos apresentados a dois personagens fundamentais do período pré-ditatorial no Uruguai: incialmente, a narrativa estabelece seu foco nos Tupamaros, grupo guerrilheiro cujo objetivo era transformar a sociedade por meio da luta armada. Em um segundo momento, apresentanos a figura de Dan Mitrione, instrutor da Escola das Américas e "teorizador" do uso da tortura como instrumento de repressão, sequestrado e morto pelos Tupamaros em 1970.

Aqui surge a especificidade da narrativa a respeito da repressão no Uruguai: ela não espera os militares tomarem o poder para iniciar. Com efeito, foi no governo do colorado Jorge Pacheco Areco que a repressão sistemática teve seu início por meio da incorporação da Doutrina de Segurança Nacional e da constituição de fronteiras ideológicas dentro da sociedade nacional (outro elemento continuamente citado ao longo dos episódios que compõem a série). Quando, em 1972, a presidência foi assumida por Juan María Bordaberry, a tortura, fosse física ou psicológica, já era uma prática frequente por parte da polícia uruguaia.

Um lugar mais nefasto, porém, aguardava Bordaberry na História: o de primeiro ditador da História uruguaia. Isso aconteceria em junho de 1973, quando, sob pressão de grandes empresários e de representantes das Forças Armadas, o então presidente resolveu 
dissolver o parlamento e proibir os partidos políticos. Os Direitos Humanos, a cultura e a educação pública passaram a ser alvos privilegiados da fiscalização, censura e repressão governamental. Bordaberry se manteria no poder até 1976, quando os próprios militares, cansados de sua marionete, assumiriam as funções de governo.

O episódio destaca que, de um total de 160 vítimas fatais do Terror de Estado no Uruguai, apenas 35 teriam sido vitimados dentro das próprias fronteiras. Os demais teriam sido assassinados em solo argentino, especialmente nas dependências do centro de detenção conhecido como "Automotores Orlett", em Buenos Aires. Tal informação enfatiza mais uma vez a abrangência e atuação da Operação Condor, da mesma forma que o apoio civil ao regime é destacado por meio da ação da imprensa, que reverberava a falsa versão de um plano de invasão comunista sobre o Uruguai. Assim como no episódio sobre a argentina, ao tratar do Uruguai a série documental reforça que um dos principais objetivos da ditadura era a adoção de medidas neoliberais, usando largamente do Terrorismo de Estado como forma de se manter no poder e controlar a sociedade pela implementação da cultura do medo:

\footnotetext{
A ditadura civil-militar tem um objetivo claro: a liberalização e desregulação da economia e implementar regras laborais mais flexíveis, a favor dos empresários e contra os direitos dos trabalhadores. O regime impulsionou o Terrorismo de Estado para evitar qualquer tipo de oposição ao seu poder econômico e político, sequestros, prisão prolongada, tortura, violações, assassinatos, desaparições e roubos de bebês formaram parte do sistema repressivo uruguaio (Encuentro, Dictaduras Latino-Americanas, Uruguai, 2016, $7: 52)$.
}

A parte conclusiva do episódio inicia com a chamada de um plebiscito por parte das Forças Armadas uruguaias em 1980, visando legitimar suas políticas e consolidar seu poder sobre a sociedade. Ainda que derrotados, os militares angariaram dois quintos dos votos válidos, o que significava $40 \%$ de apoio popular ao regime naquele momento. Todavia, iniciava ali o processo de transição democrática, que seria concluído apenas em 1984 com a realização de eleições presidenciais nas quais sairia vencedor Julio Maria Sanguinetti, que devolveu os funcionários públicos cassados aos seus postos e anistiou os presos políticos que haviam lutado pelo retorno da democracia, mas que igualmente 
promulgou a "Ley de Caducidad", conferindo imunidade legal aos responsáveis pela implantação do Terror de Estado no Uruguai.

O episódio dedicado ao Paraguai se diferencia pelas características de seu próprio objeto: a larga duração da ditadura paraguaia (1954-1989), bem como sua centralidade na figura do General Alfredo Stroessner estabelecem a linha narrativa específica desse episódio. Todavia, a fragilidade do sistema político paraguaio, que teve 44 presidentes em 84 anos ( 24 dos quais destituídos de forma violenta), é algo ressaltado logo no início da narrativa. Assim, a ideia de estabilidade política conferida por Stroessner é apontada como um dos motivos que conferiram longevidade ao regime. Outra explicação (complementar) estaria na aprovação pelo Congresso Nacional, em 1967, de uma lei assegurando a reeleição presidencial indefinidamente.

Em 04 de maio de 1954 iniciou no Paraguai um longo processo repressivo. Foram 35 anos de violações aos Direitos Humanos, detenções arbitrárias, torturas, sequestros e assassinatos. As forças de segurança respondiam apenas a um ditador, o general Alfredo Stroessner. (Encuentro, Dictaduras LatinoAmericanas - Paraguay, 2016, 1:15).

O episódio a respeito da ditadura paraguaia apresenta um verdadeiro misto de elementos que ressaltam sua especificidade com outros que compõem uma narrativa mais geral acerca das ditaduras sul-americanas. Por um lado, a implantação pública do ideário da Doutrina de Segurança Nacional estabelecendo as fronteiras ideológicas internas e a consequente associação do regime ao Plano Condor. Ao mesmo tempo, a ação do Estado sobre o sistema educacional, que foi muito além da repressão a professores e estudantes. O documentário reforça o caráter anticomunista do discurso oficial, materializado na elaboração de livros escolares que ensinavam que o ditador havia logrado uma convivência pacífica, democrática e ordenada dentro do Paraguai, enquanto outros países sofreriam com as mazelas da luta contra o comunismo. Assim, o documentário faz questão de enfatizar e associar o controle do aparato estatal (para ingressar no serviço público era necessário ingressar no Partido Colorado de Stroessner) à forte vinculação ao histrionismo anticomunista vindo dos Estados Unidos (Stroessner foi classificado pelo presidente Richard Nixon como o "Campeão do Anticomunismo na América Latina).

Ainda dentro das similitudes com outros regimes, a crise econômica da década de 1980 passa a evidenciar os limites e fissuras existentes dentro da ditadura paraguaia. 
Novamente, ao lado deste elemento de crise, surge a questão dos Direitos Humanos: o saldo deixado pelo final do regime, derrubado por um novo golpe militar em 1989, é apresentado como sendo de 20 mil prisões arbitrárias, 59 execuções extrajudiciais, 336 desaparecimentos e 3.500 exilados.

O episódio relativo ao Brasil inicia evidenciando as conexões entre a ditadura e o poder econômico por meio da figura já citada de Henning Albert Boilesen. O ponto de partida, contudo, está no governo João Goulart e na oposição exercida pelos setores conservadores da sociedade que, em oposição às reformas preconizadas, apoiaram o golpe civil-militar de 31 de março de 1964. A narrativa dos primeiros anos do regime está centrada na figura do General Castelo Branco, bem como na implantação da política econômica que conduz ao chamado “Milagre Brasileiro” do período Médici (1969-1974), período de opulência e consumo para a classe média, mas também de aumento das desigualdades sociais, da miséria e da fome. A especificidade da ditadura civil-militar brasileira é, então, ressaltada:

Diferentemente de outras ditaduras, o regime estimulou a indústria em vez de
destruí-la, frente a uma América Latina em crises. Entre 1968 e 1973, o país se
transformou na $8^{\text {a }}$ economia mundial (...). Mas, o oposto a isto foi a miséria e
a fome. O Brasil adotou um plano de ajustes editado pelo Fundo Monetário
Internacional, que enfrentava a inflação através da redução de salários. Na
década de 1970, a pobreza afetava 40\% dos brasileiros, na Argentina $8 \%$ (...).
(Encuentro, Dictaduras Latino-Americanas - Brasil, 2016, 6:00).

Novamente, a crise econômica a partir de 1974 é apontada como eixo explicativo para a crise política do regime. A associação entre crise econômica e crise política eclipsou aspectos importantes no processo de redemocratização como o aparecimento de uma nova esquerda, a emergência dos Direitos Humanos com questão cara às oposições internas e às relações exteriores, inclusive com os Estados Unidos. Todavia, dois detalhes, por vezes esquecidos, integram a narrativa construída por Encuentro a respeito do Brasil. Em primeiro lugar temos a lembrança de que caberia ao Brasil a primazia na implantação da Doutrina de Segurança Nacional, criando fronteiras ideológicas dentro de seu próprio território, o que levaria o país a colaborar com outros regimes ditatoriais na organização de seus aparatos repressivos, notadamente Chile e Uruguai, para além dos fortes laços estabelecidos com a ditadura boliviana. Por outro lado, somos rememorados da 
Operación Murciélago, uma ação coordenada entre as forças repressivas de Brasil e Argentina entre 1978 e 1979 com o objetivo de eliminar integrantes do grupo Montoneros que tentavam regressar clandestinamente àquele país.

Estabelecendo uma ligação coerente com as demais narrativas que integram o conjunto de documentários, o episódio relativo ao Brasil apresenta o declínio da ditadura civil-militar como um evento associado à crise econômica que perpassa o continente durante os anos 1970 e que leva à perda de apoio por parte do regime e à reorganização da sociedade civil, especialmente a partir das greves conduzidas pelos metalúrgicos do ABC paulista no fim daquela década, pondo em cena as contradições da sociedade brasileira, mas também o surgimento de novas lideranças políticas, personificadas na narrativa em Luís Inácio Lula da Silva. Ao fim, é apresentado o saldo de 434 mortos e desaparecidos e a permanência da impunidade aos responsáveis pelo terror e pela repressão. Novamente, o passado e o presente se reencontram nos apoios políticos e alianças do governo Kirchner.

O episódio a respeito da ditadura boliviana tem seu marco inicial com a ascensão de Victor Paz Estenssoro ao comando da nação em 1952. Representante do Movimento Nacionalista Revolucionário, Estenssoro buscou implantar um conjunto de políticas nacionalistas que encontrariam oposição junto aos setores mais conservadores da economia. Em 1964, já em seu segundo mandato, Estenssoro foi derrubado por um golpe que conduziu ao poder seu vice-presidente, René Barrientos, representando os militares bolivianos. O destaque então passa a ser dado à abertura da economia boliviana ao capital estrangeiro, em oposição às diretrizes até então tomadas. Foi também sob a batuta de Barrientos que as forças armadas bolivianas prenderam e executaram Che Guevara, o que lhes conferiu certa visibilidade dentre as forças conservadoras latino-americanas naquele momento. Em 1969, Barrientos faleceria em um acidente aéreo, e a política boliviana passaria por nova reviravolta, uma vez que os militares que lhe sucederam optaram por implantar medidas francamente progressistas - inclusive criando milícias populares -, o que foi visto como algo intolerável pelos grupos mais conservadores das Forças Armadas e pelo governo dos Estados Unidos.

Estruturou-se assim um novo golpe de Estado em 1971, que levou ao poder o general Hugo Banzer Soares, que governou até 1978 com o apoio do Movimento 
Nacionalista Revolucionário de Estenssoro. Seguindo o receituário neoliberal clássico, Banzer abriu a economia boliviana para o capital estrangeiro, implantando uma política de arrocho salarial que conduziu a um brutal aumento no custo de vida para os segmentos mais empobrecidos da população. Tais segmentos seriam especialmente atingidos em 1974 pela retirada de subsídios para uma série de gêneros de primeira necessidade, o que aumentaria o quadro de miséria. Aos protestos dos camponeses, o governo de Banzer respondeu com a repressão, em um massacre que ficaria conhecido como o "Banzerato". No mesmo ano, Banzer promoveria um autogolpe, eliminando partidos políticos e concentrando o poder político sobre sua pessoa. A Bolívia ingressaria assim no rol dos países a adotarem a Doutrina de Segurança Nacional e a estabelecerem fronteiras ideológicas em sua sociedade. A precariedade da situação econômica, no entanto, foi um freio forte para que Banzer encontrasse na sociedade boliviana o apoio que imaginava encontrar. O pouco apoio que lhe restava dissolveu-se em 1977, quando tornaram-se públicas suas negociações com o ditador chileno Augusto Pinochet para efetivar uma troca de territórios visando conferir à Bolívia a retomada de uma saída territorial para o mar.

Um papel importante na narrativa construída a respeito da ditadura boliviana está na greve de fome que iniciou em 28 de dezembro de 1977 por quatro esposas de mineiros exilados, pedindo anistia, trabalho para os mineiros demitidos após as greves e a retirada das forças militares dos postos de trabalho. Essa ação das mulheres é considerada fundamental para a reorganização da sociedade civil e sua luta contra a ditadura:

Em 28 de dezembro de 1977, quatro mulheres de mineiros exilados ingressaram na principal igreja de La Paz e iniciaram uma greve de fome. Em 31 de dezembro, se somou um segundo grupo de mulheres. (...) Depois de 14 dias mais de quinhentas pessoas e a meados de janeiro superavam as mil pessoas. Pediam uma anistia geral para todos os presos políticos e exilados. Trabalho para os mineiros despedidos (...) e a retirada das tropas dos postos de trabalho. (Encuentro, Dictadura Latino-Americanas, Bolívia, 2016, 11:02).

A situação de declínio do regime, no entanto, se estenderia até 1982, em meio a eleições fraudulentas, repressão e greves gerais.

A narrativa a respeito da Venezuela talvez seja a que se apresente com mais elementos particulares, uma vez que seu recorte temporal é específico. Com efeito, o 
episódio inicia se remetendo ao ano de 1922, quando a descoberta de petróleo traz ao país, até então marcado pela predominância de uma estrutura agrária, uma nova matriz econômica. De modo semelhante, somos apresentados ao caráter incipiente da democracia venezuelana, pois apenas em 1947 o povo teria a oportunidade de eleger um presidente por meio do voto livre, secreto e universal. O eleito foi Rômulo Gallegos, representando a centro-esquerda. Ficou nove meses no poder. Em 1948, um golpe militar conduziu ao poder uma junta de militares que representava as instituições petroleiras ameaçadas pelo governo de Gallegos. Dentre os militares que compunham tal junta estava Marcos Pérez Jiménez, que em pouco tempo se tornaria presidente absoluto por meio do recurso às fraudes eleitorais.

Calcado no dinheiro do petróleo, o governo de Jiménez buscou implantar uma nova fisionomia ao país, começando pela capital, Caracas. A grande quantidade de obras públicas visando modernizar a cidade impôs um clima de modernidade, ao mesmo tempo em que as classes altas e médias assumiam hábitos da sociedade de consumo estadunidense, em um processo que bem poderia ser classificado como "Milagre Venezuelano". Longe dos holofotes, o curta destaca que a pobreza, a fome e a miséria atingem a maior parte da população. Os direitos políticos foram suprimidos e a implantação de um regime de terror era assegurada pela "Dirección de Seguridad Nacional", órgão comandado pelo chefe de polícia Pedro Estrada. Em junho de 1953, no caso que talvez seja um dos mais emblemáticos a envolver a "Direccón", o poeta e jornalista Antonio Pinto Salinas foi detido e executado na beira de uma rodovia. A grande imprensa, contudo, dava apoio aberto ao regime, noticiando apenas seus grandes feitos e exaltando seu discurso de celebração nacional. Pela sua localização e sua riqueza, a Venezuela sob Pérez Jiménez era peça fundamental no tabuleiro da Guerra Fria naquele momento.

O quadro de intensas violações aos direitos humanos, bem como a massiva miséria da população levaram a igreja católica venezuelana a divulgar uma carta de denúncia, em 1957, por ocasião do dia do trabalho. Ao mesmo tempo, o petróleo venezuelano passou a encontrar um forte concorrente na produção do mundo árabe, agravando a situação de crise e esvaindo o pouco apoio que Jiménez ainda encontrava. Novamente, temos a associação pelo curta-metragem da perda de legitimidade do regime 
à violação dos direitos humanos e à crise econômica. Aqui, como no caso das demais ditaduras, a resistência civil, pacífica, de caráter democrático é considerada um ponto fundamental na queda do regime ditatorial:

\begin{abstract}
Os protestos cresceram. As forças de oposição começaram a crescer. De mão em mão, em silêncio, com a cumplicidade de toda a população, os partidos políticos distribuíram planfletos que chamaram a uma greve geral que se realizaria em 21 de janeiro de 1958. Neste dia, depois das 12h, todo o país ficaria paralisado. Caracas permanecia deserta. As medidas de protestos continuariam. (Encuentro, Dictaduras Latino-Americanas, Venezuela, 2016, $11: 10)$.
\end{abstract}

No início de 1958, um movimento conduzido por civis e militares apeou Jiménez do poder e, ao fim do ano, Rômulo Betancourt foi eleito presidente da Venezuela. Seu governo implantou uma política de respeito aos Direitos Humanos, mas deu continuidade às práticas econômicas do período anterior. A ditadura venezuelana, dessa forma, geraria um quadro de pobreza estrutural que vigoraria por décadas no país.

O Chile é abordado a partir da ascensão de Salvador Allende ao poder em 1970, seguindo-se a nacionalização do cobre, a realização da Reforma Agrária, a nacionalização do sistema financeiro, bem como de numerosas indústrias dentro do país. Diante desse conjunto que visava implantar o socialismo pela via eleitoral, Allende passou a enfrentar a oposição dos Estados Unidos, que financiam greves de mineiros e caminhoneiros, paralisando a economia nacional. As tensões levariam ao golpe de onze de setembro de 1973, quando se implantou uma das mais sanguinárias e duradouras ditaduras da América Latina. No curta-metragem, o forte anticomunismo e a interferência dos Estados Unidos na desestabilização do governo Allende e no golpe são destacados. Implantando um modelo que posteriormente seria seguido pela Argentina, o Chile sob Pinochet transformaria o país em uma grande cadeia de campos de concentração, muitos dos quais localizados em regiões extremamente frias e desabitadas do país, onde os prisioneiros eram submetidos a trabalhos forçados, torturas e, em muitos casos, à morte.

Na busca pela implantação de uma nova ordem social, os militares promoveram por meio do terror uma cultura de medo na população. Criou-se uma educação autoritária, baseada no medo, no acatamento e submissão às ordens. Três anos após o golpe, o governo criou, com o apoio da classe latifundiária, a Dirección de Inteligencia Nacional (DINA), uma polícia de caráter político com ampla liberdade para investigar, deter e 
executar. O curta ainda destaca a adoção das políticas econômicas neoliberais que posteriormente almejariam a posição de hegemonia no mundo. O resultado, por si já conhecido, é o aumento exponencial da miséria, acompanhado nesse caso da exclusão dos pobres aos direitos mais básicos outrora oferecidos pelo Estado, tais como educação e saúde. É também destacado, pelos recursos ao narrador e à animação, que foi no Chile, em 1975, que tomou forma o Plano Condor, quando as ditaduras do Cone Sul se reuniram para promover a repressão contra seus opositores, identificados como inimigos internos dentro do espectro da Doutrina de Segurança Nacional:

\section{IMAGEM 4}

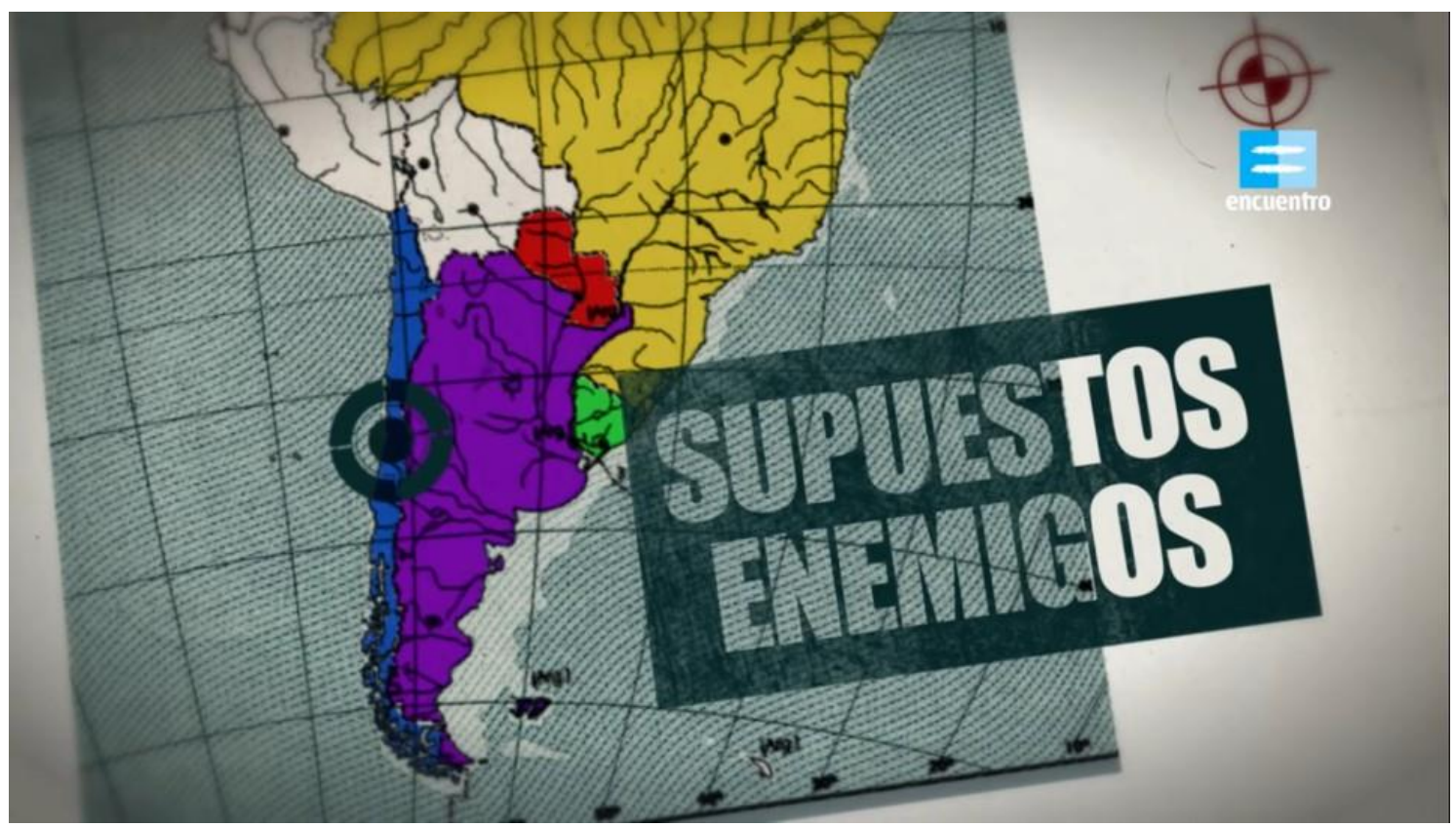

Fonte: Canal Encuentro, Dictaduras Latino-Americanas, Chile, 2016, 7:34. https://www.youtube.com/watch?v=YACzkiLMVLc\&list=PLD9uJ4b9DO5DY1ETfre1uoOT1j2tNZ19m \&index=7 acesso: 20/12/2019

Assim, o tripé que marcaria todas as demais experiências latino-americanas, ainda que com ênfases diferentes, se encontraria no caso chileno: intervenção dos EUA na política dos países latino-americanos, Plano Condor, Terrorismo de Estado. No caso da adoção das políticas neoliberais, elas serão sempre lembradas como exemplo de 
destruição de direitos e agravamento das desigualdades, ainda que nem todas as ditaduras tenham adotado explicitamente tal modelo econômico.

As brechas de oposição eram poucas e perigosas. Assim, já em 1973, a cúpula católica chilena criou o Comitê Pró-Paz. As fissuras na estrutura pinochetista, porém, teriam que esperar a ascensão de Jimmy Carter nos Estados Unidos, que incorporaria ao governo estadunidense uma ideia de preocupação com os Direitos Humanos na América Latina, levando à oposição norte-americana aos crimes perpetrados pelo estado chileno. Ao lado da forte repressão, o curta destaca que o regime de Pinochet encontrava na sociedade apoios, silêncios e consentimentos. Em 1978, por exemplo, o ditador levou a cabo uma consulta nacional acerca de seu governo. O resultado de $75 \%$ de votos favoráveis não logrou o reconhecimento de muitos organismos internacionais, uma vez que o plebiscito se realizara sem registros eleitorais. Dois anos mais tarde, diante de nova consulta, seu regime obteve $67 \%$ de aprovação. Esta alta taxa aparece na narrativa sendo contrastada com os números de presos, mortos e desaparecidos. Nesse momento, a ditadura chilena já havia assassinado mais de 15 mil pessoas, havia 2.200 desaparecidos; 164 mil chilenos estavam no exílio e mais de 150.000 estavam presos em campos de detenção, sendo oitenta por cento destes operários ou camponeses.

Amparado pelo discurso anticomunista e pelas práticas econômicas neoliberais, a sanguinária ditadura de Pinochet logrou sobreviver à década de 1980, sendo derrotada em novo plebiscito, realizado em fins de 1989. Ainda assim, a derrota lhe conferiu $43 \%$ de votos válidos, escancarando o amplo apoio que o regime ainda encontrava na sociedade civil chilena. O curta fez questão de marcar que o processo de transição no Chile não significou a adoção de uma Justiça de Transição, fazendo reinar a impunidade contra os perpetradores do arbítrio. Como demonstra a película, Patrício Alwin seria eleito presidente no final daquele ano, em uma transição para a democracia eivada de concessões à ditadura e que deixou intocada a matriz econômica neoliberal. Pinochet, livre de acusações por seus crimes, seguiria como comandante em chefe do exército e, posteriormente, senador vitalício.

Chegamos, por fim, à narrativa sobre a ditadura equatoriana. Tal qual o caso venezuelano, essa narrativa é perpassada pela presença do petróleo, que no Equador concentrava-se, até 1972, sob o controle de empresas transnacionais. No início daquele 
ano, um golpe de Estado conduziu ao poder Guillermo Rodriguez Lara, ex-aluno da Escola das Américas que, paradoxalmente, apresentava-se como um homem de esquerda. Lara levou o país andino a integrar a Organização dos Países Produtores de Petróleo (OPEP) e estimulou a realização da reforma agrária no país. Em 1974, Lara chegou a estatizar 51\% da Texaco-Gulf Company no Equador, mas acabou retrocedendo dessa decisão diante de boicote patrocinado pela companhia. Aliando o conservadorismo a políticas sociais, o governo de Guillermo Lara é apresentado na narrativa como "repressivo sem implementar o terror". Ainda assim, seria deposto pelas forças armadas equatorianas em 1976. O Equador passou então a ser governado por um triunvirato militar até 1978, quando Jaime Roldós Aguilera foi eleito. Seu governo, no entanto, foi interrompido por um acidente aéreo em 1981.

A narrativa é retomada em 1984, com a eleição de León Febres-Cordero Ribadeneyra. Destaca-se, novamente, o impacto das políticas neoliberais no aviltamento de direitos dos cidadãos. Em seu governo, a economia equatoriana foi aberta ao mercado, gerando concentração de renda, arrocho salarial e aumento da miséria. Diante dos protestos sociais, o governo Ribadeneyra promoveu práticas sistemáticas de violação aos Direitos Humanos, desaparecimentos e execuções sumárias. Nas mãos de uma democracia, alojava-se um plano sistemático de repressão, sendo o principal alvo a organização clandestina "Alfaro Vive, Carajo (AVC)", que defendida uma política de redistribuição de terras no Equador. A repressão organizada apenas encontraria seu termo com a eleição e posse de Rodrigo Borja, representante da esquerda democrática, em 1988. A política econômica neoliberal, no entanto, permaneceria intocada.

Os oito curtas-metragens traçam assim um panorama da história das Ditaduras de Segurança Nacional sul-americanas, com destaque para as violações de direitos humanos, as medidas neoliberais e o aumento das desigualdades sociais. A centralidade da História Política não impede a construção de uma história do processo de modernização capitalista dessas sociedades, fortemente marcado pela concentração de renda e pelo aumento das desigualdades sociais. 


\section{Considerações Finais}

As disputas de memória em torno dos temas sensíveis, sobretudo no amplo quadro do processo de Justiça de Transição, tornam os sentidos produzidos pelo audiovisual um objeto de fundamental importância para as pesquisas históricas. As representações desse passado revelam também os projetos políticos em curso e as batalhas pela autoridade sobre determinada leitura do passado. A cultura da memória também favorecia o interesse do grande público em produtos culturais que funcionam como produtores de sentidos sobre o passado. No caso dos curtas-metragens da série Dictaduras latino-americanas do Canal argentino Encuentro, de 2016, fica explícito o impacto do processo de Justiça de Transição empreendido no país, sobretudo a partir do governo de Nestor Kirchner. O eixo do documentário se concentra na reprodução de uma memória que vai se consagrando como política na Argentina e que tem como sustentação a valorização dos Direitos Humanos. Somam-se a isso as possibilidades de acrescentar críticas ao modelo neoliberal como nefasto à consagração de um Estado de Direito quando isso é possível, afinal, nem todas as ditaduras adotaram o modelo neoliberal.

Os oito curtas-metragens constituem, sem dúvida, um importante material na popularização da gravidade das sistemáticas violações de direitos humanos na América Latina produzidas por governos ditatoriais. O caráter pedagógico, com o cuidado ético necessário para a representação da violência de Estado, é um ponto forte dessa produção. Contudo, ao longo dos curtas, é possível observar certo desconhecimento acerca das histórias nacionais retratadas, incluindo simplificações que não encontram ressonância no conhecimento histórico produzido. Esse é o caso, por exemplo, de afirmarem que as famosas Marchas com Deus, organizadas pelas mulheres de classe média no Brasil, seriam fruto do financiamento norte-americano. O papel dos EUA no processo de desestabilização de regimes democráticos na América Latina e apoio às ditaduras vem sendo bastante pesquisado pelos historiadores latino-americanos e é inegável.

A excessiva linearidade e certos comportamentos simplificados dos atores e personagens envolvidos com esse passado recente fragilizam os curtas-metragens. Sem dúvida, a produção audiovisual, ainda que de caráter documental, não terá o mesmo objetivo de pesquisas acadêmicas empenhadas em esclarecer ao máximo as relações 
complexas entre as ditaduras e seus projetos de poder. Com isso, a produção audiovisual não deve ser entendida como um tradutor para o grande público das narrativas históricas. Ao produzir sentidos sobre o passado, estabelecem necessariamente relações imbricadas com as disputas pela memória, a História e os projetos de futuro estabelecidos pelos diferentes grupos que concorrem entre si pela autoridade para construir representações da sociedade no qual vivem. A análise crítica desse material não inviabiliza o seu uso ou desqualifica o projeto. Ao contrário, seu principal mérito é justamente demonstrar a adoção sistemática de métodos repressivos que atentaram contra os próprios cidadãos e promoveram graves violações de Direitos Humanos. Além disso, a opção comparativa entre as ditaduras da América Latina favorece a compreensão do processo histórico para além das experiências nacionais específicas, demonstrando a importância de análises que articulem o nacional e o transnacional. Ao mesmo tempo, explicita a percepção das escolhas realizadas pelos produtores, das diversas memórias circulantes e em disputa, dos dissensos no campo historiográfico, ampliando a nossa consciência histórica sobre o vivido. Vale destacar a importância desse material enquanto parte da construção de lugares de memória, que no caso argentino tem se tornado importante dentro do processo de Justiça de Transição. Por fim, o esforço do canal Encuentro em pensar as diferentes ditaduras latino-americanas e seus pontos de contato revela o olhar atento do Estado argentino para a História recente de todo o subcontinente.

\section{Referências Bibliográficas}

BRITO, Alexandra, GONZÁLEZ-ENRÍQUEZ, Carmen; FERNÁNDEZ, Paloma Aguilar. Política da memória: verdade e justiça de transição para a democracia. Lisboa: Ed. Imprensa de Ciências Sociais/Universidade de Lisboa, 2004. pp. 155-194.

BURGUESS, Jean, GREEN, Joshua. Youtube e a revolução digital: como o maior fenômeno da cultura participativa transformou a mídia e a sociedade. Trad. Ricardo Giassetti. São Paulo: Aleph, 2009.

CORTE, Malena. Reflexiones em torno al propósito educativo de Canal Encuentro. Revista Questión. La Plata, vol.1, n. 51, julho a setembro de 2016. p. 360-375.

DÍAZ, Cecília Beatriz. Encuentro. Inicio hacia una comunicación democrática. Revista tram(p)as de la comunicacion y la cultura. N.75, dezembro de 2013. p.39-44. 
DURÁN, Laura, LITVINOFF, Laura, ROLDÁN, Daniel, TOMASSONI, Paula. Canal Encuentro y el relato de la historia reciente. <http://conti.derhuman.jus.gov.ar/2016/11/seminario/mesa_10/duran_litvinoff_mesa_10 .pdf> acesso em: 15/01/2020.

ENCUENTRO.

Dictaduras

latino-americanas.

<http://encuentro.gob.ar/programas/serie/9211 > acesso em: 12/12/2019.

HUYSSEN, Andreas. Culturas do passado-presente. Modernismos, artes visuais, políticas da memória. Rio de Janeiro: Contraponto; Museu de Arte do Rio, 2014.

LIDDINGTON, Jill. O que é história pública? In: ALMEIDA, Juliele Rabêlo e ROVAI, Marta Gouveia de Oliveira (org.) Introdução à História Pública. São Paulo: Letra e Voz, 2011, p.31-52.

LVOVICH, Daniel e BISQUERT, Jaquelina. La cambiante memória de la ditadura. Discursos públicos, movimentos sociais e legitimidade democrática. Los Polvorines: Universidade Nacional de General Sarmiento: Buenos Aires, Biblioteca Nacional, 2008.

MEZAROBBA, Glenda. Do que se fala, quando se diz "Justiça de Transição"? BIB: Revista Brasileira de Informação Bibliográfica em Ciências Sociais. São Paulo, vol. 41, 111-122, 1996.

PADRÓS, Enrique. América Latina: Ditaduras, Segurança Nacional e Terror de Estado. História e luta de classes. n.4, julho de 2007, p.43-49.

RAMOS, Fernão. Mas, afinal...o que é mesmo um documentário? São Paulo: Senac, 2008. 